\title{
DAMPAK KEKUATAN INFORMASI FILM NGENEST TERHADAP PENILAIAN KOMUNITAS STAND UP INDONESIA DI JAKARTA
}

\author{
Rustono Farady Marta dan Angelina Suryani \\ Program Studi Ilmu Komunikasi - Universitas Bunda Mulia, Jl. Lodan Raya No. 2, Jakarta \\ Utara 14430, No. HP: +6285232961203 dan +6281 2104 5619, \\ Email: rustonofarady@gmail.com dan angelina.suryani@yahoo.com
}

\begin{abstract}
This research examines the influence of information strength on NGENEST The Movie towards social judgment. This topic has appointed based on facts that the delivery of anti-discrimination message is expected can inffluence Indonesian people about Bhinneka Tunggal Ika (unity in diversity). The purpose of this study is to find effects of a message on NGENEST The Movie towards social judgment. This research is using quantitative method with positivistic and explanative approaches.Data were colected through by questionnaires to 91 members of Stand Up Indonesia community in Jakarta, and supported by secondary data obtained from literature. Hypotheses testing has been done by doing correlation test, regression, coefficient of determination and $t$-test. The result shows that information strength on NGENEST The Movie has significant relation towards social judgment. The result of linear regression has been indicated by equation $Y=3,037+0,365 X 1$, with the result of hypotheses testing stating that the variable of information strength on NGENEST The Movie has significant impact on social judgment, contributing to $17,9 \%$. It can be concluded that the information strength on NGENEST The Movie has significant impact towards social judgment.
\end{abstract}

Keywords: persuasive communication, information strength, film, social judgment, anti-discrimination

\begin{abstract}
Abstrak
Penelitian ini membahas mengenai pengaruh kekuatan informasi pada film NGENEST terhadap penilaian masyarakat. Topik ini diangkat berdasarkan fakta-fakta bahwa penyampaian pesan anti diskriminasi diharapkan dapat mempengaruhi pola pikir masyarakat Indonesia mengenai Bhinneka Tunggal Ika. Tujuan dari penelitian ini adalah untuk mengetahui pengaruh isi pesan film NGENEST terhadap penilaian masyarakat. Penelitian ini menggunakan metode kuantitatif dengan paradigma positivistik dan bersifat eksplanatif. Teknik pengumpulan data dilakukan melalui penyebaran kuesioner terhadap 91 sampel anggota komunitas Stand Up Indonesia di Jakarta, serta didukung dengan data sekunder yang didapatkan melalui sumber kepustakaan. Pengujian hipotesis dilakukan dengan uji korelasi, regresi, koefisien determinasi, dan uji t. Hasil pengolahan data menunjukkan bahwa variabel kekuatan informasi pada film NGENEST memiliki tingkat hubungan yang cukup berarti terhadap variabel penilaian masyarakat. Hasil regresi linear ditunjukkan dengan persamaan $\mathrm{Y}=3,037+0,365 \mathrm{X} 1$, dengan hasil pengujian hipotesis yang menyatakan bahwa variabel kekuatan informasi pada film NGENEST memiliki pengaruh yang signifikan terhadap penilaian masyarakat, dengan kontribusi sebesar 17,9\%. Berdasarkan hasil penelitian tersebut, maka dapat disimpulkan bahwa kekuatan informasi pada film NGENEST dapat memberikan pengaruh yang signifikan terhadap penilaian masyarakat.
\end{abstract}

Kata kunci: komunikasi persuasif, kekuatan informasi, film, penilaian masyarakat, anti-diskriminasi

\section{Pendahuluan}

Film merupakan salah satu ragam media komunikasi massa yang mengemas audio dan visual sedemikian rupa, sehingga menghasilkan suatu karya yang menarik, tidak membosankan dan mudah diingat penonton karena memiliki alur cerita yang menarik. Film adalah karya seni budaya yang merupakan pranata sosial dan media komunikasi massa yang dibuat berdasarkan 
kaidah sinematografi dengan atau tanpa suara dan dapat dipertunjukkan (UndangUndang No. 33 Tahun 2009 Pasal 1). Film sebagai bagian dari media komunikasi massa, selain memberikan hiburan kepada penonton juga berfungsi sebagai sarana informatif, edukatif maupun persuasif.

Fungsi film sendiri dijelaskan dalam UU Perfilmanyaitumencakupbudaya,pendidikan, hiburan, informasi, pendorong karya kreatif, dan ekonomi. Selain itu, dijelaskan juga bahwa tujuan film adalah untuk membina akhlak mulia, mewujudkan kecerdasan kehidupan bangsa, memelihara persatuan dan kesatuan bangsa, meningkatkan harkat dan martabat bangsa, mengembangkan dan melestarikan budaya bangsa, memperkenalkan budaya bangsa kepada dunia internasional, meningkatkan kesejahteraan masyarakat, dan mengembangkan film berdasarkan budaya bangsa yang hidup dan berkelanjutan.

Film dibuat dengan berbagai macam genre atau jenis agar tetap dapat menjunjung asas-asas kebudayaan melalui tampilan yang menarik. Topik film yang diangkat bisa berdasarkan kisah nyata, fiksi, ataupun campuran keduanya. Beberapa jenis film diantaranya adalah film laga atau aksi, yang menampilkan efek dan adegan yang menegangkan, atau film horor yang menyajikan ketakutan mistis bagi penontonnya, didukung dengan unsur musik dan setting yang menyeramkan.

Jenis film komedi merupakan salah satu genre yang cukup berkembang di Indonesia. Film komedi membawakan tema-tema yang lucu, aneh dan konyol, sehingga menggelitik penonton dan mengundang tawa. Pada tahun 2014, data menunjukkan bahwa film komedi menjadi tema yang paling digemari oleh masyarakat Indonesia, yaitu sebesar 33,4\%.

Di samping itu, karena fungsi dan tujuan film terutama adalah untuk menjunjung budaya dan bangsa Indonesia, maka cerita-cerita yang diangkat seringkali membawa identitas berbagai suku dan budaya Indonesia. Identitas sebagai etnis Tionghoa di Indonesia merupakan salah satu tema budaya yang diangkat dalam perfilman Indonesia. Pembawaan tema film yang menampilkan etnis Tionghoa pada umumnya menggambarkan kehidupan etnisitas mereka yang hanya dianggap sebagai warga pendatang di Indonesia, sehingga mereka kerap menerima perlakuan berbeda dari masyarakat Indonesia. Seperti dikatakan oleh Hanung Bramantyo, film bisa dijadikan basis pemantik gerakan sosial, terutama di kalangan generasi muda. Pemikiran ini juga didukung oleh Yayasan

Tabel 1. Rating Genre Film di Indonesia

\begin{tabular}{cc}
\hline Genre & Rating \\
\hline Komedi & $33,4 \%$ \\
Cinta & $28,4 \%$ \\
Aksi Laga & $18,4 \%$ \\
Sejarah & $7,9 \%$ \\
Anak & $5,2 \%$ \\
Horor & $3,6 \%$ \\
\hline
\end{tabular}

Sumber: tribunnews.com 
Denny JA, bahwa gerakan anti diskriminasi sengaja didorong melalui film, karena dampaknya lebih massif dan efektif.

Aksi diskriminasi terhadap keturunan Tionghoa terjadi sejak zaman kolonial Belanda hingga Orde Baru. Di zaman Orde Baru, diskriminasi ini juga diperkuat dengan adanya larangan dari pemerintah terhadap hal-hal yang berbau Tionghoa termasuk kegiatan keagamaan, kepercayaan, serta adat istiadat Tionghoa tidak diakui di Indonesia. Namun, sejak Reformasi, khususnya sejak pemerintahan Gus Dur, negara mengakui eksistensi mereka sebagai bagian dari Republik ini yang pantas dihormati dan dilindungi seperti warga negara pada umumnya. Diskriminasi sosial juga kerap dirasakan oleh para warga keturunan Cina di Indonesia. Salah satu contoh diskriminasi yang dialami anakanak sekolah adalah tindakan 'bullying', hinaan, ejekan dan pemalakan yang kerap menjadi makanan sehari-hari anakanak warga keturunan Cina di Indonesia (Suryadinata, 2010).

Berdasarkan unsur historis tersebut, Starvision membuat film dengan judul NGENEST. Film ini memaparkan tentang fenomena sosial yang kerap terjadi dan dialami banyak orang dari etnis Tionghoa (orang Cina di Indonesia). Permasalahanpermasalahan seperti yang ditampilkan pada film NGENEST tidak sekedar cerita fiksi belaka, melainkan kisah nyata yang juga dialami Ernest sendiri. Hal pertama yang dilakukan oleh etnis Tionghoa sebagai sebuah kelompok demi mengubah nasib mereka adalah mengusahakan agar mereka diterima sepenuhnya sebagai bagian dari bangsa Indonesia.

Alur cerita yang digambarkan dalam film ini diangkat dari kisah nyata dan pengalaman yang dialami oleh Ernest sejak menginjak bangku SD. Ia sebagai orang keturunan Tionghoa sering mendapatkan perlakuan semena-mena dari teman-teman sekolahnya.

Pengalaman-pengalaman menjadi korban bully ini membuat Ernest mencari cara agar keturunannya kelak tidak mengalami hal yang sama. Ia bertekad untuk menikahi seorang wanita pribumi dengan harapan keturunannya memiliki darah pribumi dan terhindar dari masalah perbedaan etnis. Inti cerita dari NGENEST ini adalah bagaimana kita berdamai dengan masa lalu yang berat dan dapat menertawakan berbagai persoalan yang kita hadapi.

Isu SARA diangkat, tetapi Ernest mengaku bahwa ia tidak takut dihujat. Seperti dilansir dalam Kompas, 3 Januari 2016, film ini seolah menagih asas Bhinneka Tunggal Ika, yang pada kenyataannya perbedaan dan keragaman itu malah dijadikan sebagai bahan penindasan. Justru selain menjadi sarana Ernest untuk berkarya, film ini juga sekaligus mengajak penonton untuk dapat melihat realita hidup bersama sebagai orang Indonesia.

NGENEST merupakan film komedi yang ditulis, disutradarai dan dibintangi oleh Ernest sendiri. Film ini merupakan cerita yang diangkat dari trilogi buku yang juga ditulis oleh Ernest, yaitu Ngenest, Ngenest 2 dan Ngenest 3 . Sejak pertama kali 
tayang perdana pada 30 Desember 2015, film NGENEST sudah berhasil menarik perhatian 710.048 penonton dalam waktu tiga minggu. Film ini juga masuk dalam daftar 10 Film Indonesia Terbaik 2015.

Berdasarkan data-data pada tabel 2, maka penelitian ini dilakukan untuk mengetahui adanya pengaruh dari kekuatan pesan dalam film NGENEST terhadap penilaian masyarakat, khususnya mengenai keragaman budaya.

Kata persuasi berasal dari bahasa Latin persuadere. Per artinya kuat, suadere artinya dorongan, sehingga persuasi berarti "dorongan yang kuat", "membujuk", atau "meyakinkan". Komunikasi persuasif merupakan komunikasi khusus yang bertujuan untuk mempengaruhi sikap, pendapat, dan perilaku seseorang baik secara verbal maupun nonverbal (Soemirat, 2014:2.1). Komponen-komponen dalam persuasi mencakup adanya tujuan, tanpa ada niat untuk menyakiti, tanpa ancaman, adanya hasil yang positif, ada pilihan lain yang tersedia, dan tidak ada pilihan yang dibatasi (Powers, 2007:126).

Teori yang dikembangkan oleh Martin Fishbein ini menjelaskan adanya pembentukan informasi dan perubahan sikap. Bermula dari konsep kognisi yang digambarkan sebagai sebuah kekuatan sistem interaksi. Pada teori ini, informasi memiliki kekuatan potensial yang dapat mempengaruhi sistem kepercayaan individu (Littlejohn, 2008:76). Terdapat dua variabel yang memiliki peranan penting dalam memengaruhi perubahan sikap, yaitu: valence dan weight. Valence (arahan atau tujuan): valence ini mengacu pada apakah informasi mendukung keyakinan Anda atau menolaknya. Suatu informasi akan dikatakan positif apabila informasi tersebut mendukung kepercayaan yang telah ada dalam diri seseorang. Sebaliknya, jika informasi dianggap tidak mendukung keyakinan, maka informasi tersebut dikatakan negatif; Weight (bobot): Bobot berkaitan dengan tingkat kredibilitas informasi tersebut. Jika seseorang berpikir bahwa informasi tersebut adalah benar, maka ia akan memberikan bobot yang tinggi pada informasi tersebut dan sebaliknya.

Teori karya Muzafer Sherif ini berfokus pada bagaimana individu membuat penilaian mengenai pernyataan

Tabel 2. Daftar 10 Film Terbaik Indonesia 2015

\begin{tabular}{cccc}
\hline No. & Judul & Tanggal Rilis & Jumlah penonton \\
\hline 1 & Surga yang Tak Dirindukan & 15 Juli 2015 & 1.523 .570 \\
2 & Single & 17 Desember 2015 & 1.318 .238 \\
3 & Comic 8: Casino Kings Part 1 & 15 Juli 2015 & 1.211 .820 \\
4 & Bulan Terbelah di Langit Amerika & 17 Desember 2015 & 917.743 \\
5 & Magic Hour & 13 Agustus 2015 & 859.705 \\
6 & Ngenest & 30 Desember 2015 & 785.413 \\
7 & Di Balik 98 & 15 Januari 2015 & 648.727 \\
8 & 3 Dara & 23 September 2015 & 666.155 \\
9 & Negeri Van Oranje & 23 Desember 2015 & 490.703 \\
10 & Air Mata Surga & 22 Oktober 2015 & 425.179 \\
\hline
\end{tabular}

Sumber: www.jadwal21.com 
yang didengarnya dan bagaimana penilaian ini akan berpengaruh pada sistem keyakinan individu (Littlejohn, 2011:105). Ia meneliti cara orang menilai pesan, sehingga tercipta istilah persepsi sosial untuk menjelaskan fenomena ini. Ketika berinteraksi dengan orang lain, kita akan bergantung pada sebuah dasar atau acuan internal yang berada di kepala kita dan didasarkan pada pengalaman sebelumnya. Tingkat penerimaan atau penolakan yang ditampilkan seseorang terhadap masalah dipengaruhi oleh adanya keterlibatan ego. Keterlibatan ego merupakan variabel penting yang diartikan sebagai hubungan personal dengan isu yang bersangkutan (Griffin, 2012:195). Terdapat enam aspek yang mempengaruhi keterlibatan ego (Wijono, 2010:25-26): diri dan penghargaan sosial (self and social esteem): self merupakan cara individu untuk bertransaksi dengan dirinya sendiri, sedangkan social esteem merupakan bentuk penghargaan yang dapat memenuhi kebutuhan sosial individu di lingkungannya; Nilai-nilai moral (moral values): nilai-nilai moral tertentu untuk melakukan penyesuaian diri dalam situasi; Ego-ideal (ego-ideals): citacita yang diharapkan untuk dapat memenuhi kebutuhan ego; Gagasan yang bermakna (meaning-ideas): gagasan bermakna yang dapat mencapai tujuan; Orang lain dan kesejahteraan mereka (other persons and their well-being): interaksi dengan orang lain yang dapat memberikan perhatian untuk meningkatkan kesejahteraan; Tujuan hidup (life goals): memiliki tujuan hidup yang jelas.

Operasionalisasi konsep yang diturunkan berupa konstruk dan variabel beserta indikator-indikator pengukurannya, dinamakan sebagai variabel karena memiliki variasi nilai yang dapat diukur. Nilai-nilai inilah yang disebut sebagai indikator (Kriyantono, 2012:26). Peneliti menetapkan dua variabel dalam penelitian ini, yaitu sebagai berikut: kekuatan informasi sebagai variabel independen (X) sebagai variabel bebas atau independen merupakan variabel yang sifatnya menerangkan variabel lain (Ardial, 2014:67). Dalam penelitian ini, peneliti menetapkan kekuatan informasi pada film NGENEST sebagai variabel independen. Selain itu, penilaian masyarakat sebagai variabel dependen (Y) sebagai variabel dependen merupakan variabel yang tingkah lakunya diterangkan oleh variabel lain (Ardial, 2014:67). Variabel dependen atau terikat merupakan variabel yang dipengaruhi atau menjadi akibat karena adanya variabel bebas. Dalam penelitian ini, peneliti menetapkan penilaian masyarakat sebagai variabel dependen.

Tabel 3. Operasionalisasi Variabel

\begin{tabular}{cccc}
\hline Variabel & Dimensi & Indikator & Sumber \\
\hline \multirow{2}{*}{ Kekuatan Informasi } & Valence & Nilai-nilai informasi persuasif & Littlejohn (2008:76) dan Soemirat \\
& Weight & Kredibilitas informasi & $(2014: 5.35)$ \\
Penilaian Masyarakat & Keterlibatan Ego & Aspek hubungan personal & Wijono \\
& & dengan isu yang bersangkutan & $(2010: 25-26)$ \\
\hline
\end{tabular}

Sumber: Hasil perumusan dan pendalaman teori 


\section{Metode Penelitian}

Paradigma dalam penelitian ini mengacu pada paradigma positivistik yang menjelaskan bahwa ada realitas yang real yang diatur oleh kaidah-kaidah tertentu yang berlaku universal, walaupun kebenaran pengetahuan tentang itu mungkin hanya bisa diperoleh secara probabilistik. Realitas berada di luar dunia subjektif peneliti dan dapat diukur dengan standar tertentu, digeneralisasi dan bebas dari konteks dan waktu. Pengujian hipotesis dalam struktur hypothetico-deductive method, melalui laboratorium eksperimen atau survei eksplanatif dengan analisis kuantitatif (Kriyantono, 2012:57).

Pendekatan pada penelitian ini dilakukan denganpendekatankuantitatif.Risetkuantitatif menggambarkan atau menjelaskan masalah yang hasilnya dapat digeneralisasikan dan tidak mementingkan adanya kedalaman data atau analisis. Peneliti pada umumnya lebih mementingkan aspek keluasan data, sehingga hasil riset dapat dianggap sebagai representasi dari seluruh populasi.

Penelitian ini menggunakan jenis penelitian eksplanatif. Jenis ini digunakan bila peneliti ingin mengetahui mengapa situasi atau kondisi tertentu terjadi, atau apa yang memengaruhi terjadinya sesuatu. Peneliti tidak hanya menggambarkan terjadinya fenomena, melainkan mencoba menjelaskan mengapa fenomena itu terjadi dan apa pengaruhnya. Peneliti menjelaskan hubungan antara dua atau lebih variabel dan dituntut untuk membuat hipotesis sebagai asumsi awal untuk menjelaskan hubungan antarvariabel yang diteliti. Analisis data menggunakan uji statistik inferensial (Kriyantono, 2012:60).
Penelitian ini dilaksanakan dari bulan Januari hingga Maret 2016 dengan menyebarkan kuesioner (baik secara langsung maupun online) kepada responden di masingmasing daerah komunitas Stand Up Indonesia Jakarta yang berada di Jakarta Pusat (Warung Waris Pasta, Matraman), Jakarta Utara (Alegro Family KTV, Artha Gading), Jakarta Barat (Café de la Papyrus, Joglo), Jakarta Timur (Warung Pewe, Duren Sawit), Jakarta Selatan (Antiloops Ribscorner, Dharmawangsa)

Populasi merupakan wilayah generalisasi yang terdiri atas obyek atau subyek yang memiliki kualitas dan karakteristik tertentu yang ditetapkan oleh peneliti untuk dipelajari dan kemudian ditarik kesimpulannya. Populasi bukan hanya sekedar jumlah, namun meliputi juga seluruh karakteristik atau sifat yang dimiliki oleh obyek atau subyek itu (Sugiyono, 2011 : 80). Penelitian ini akan dilakukan terhadap komunitas Stand $U p$ Indonesia se-Jakarta, sehingga populasinya mencakup seluruh anggota komunitas Stand Up Indonesia se-Jakarta yang berjumlah sebanyak 117 orang.

Metode pengambilan sampel yang digunakan peneliti adalah dengan menggunakan pengambilan sampel secara acak (probability sampling). Teknik pengambilan sampel yang peneliti gunakan adalah dengan teknik simple random sampling yang merupakan teknik pengambilan sampel secara sederhana dan dilakukan secara acak. Berdasarkan banyaknya populasi, peneliti menggunakan rumus Slovin untuk menentukan ukuran sampel yang diperlukan. Jadi pada penelitian ini, banyaknya jumlah sampel atau total responden yang harus diteliti adalah 91 orang. 
Dalam melakukan penyebaran kuesioner untuk sampel pra uji, peneliti mengumpulkan data dengan mendatangi lokasi-lokasi tempat diadakannya kegiatan open mic untuk komunitas Jakarta Utara dan Jakarta Pusat. Sedangkan untuk komunitas Jakarta Barat, Jakarta Timur dan Jakarta Selatan, peneliti berusaha mendapatkan data melalui kuesioner online karena adanya kendala jarak dan waktu yang harus ditempuh peneliti. Kegiatan pra uji dimulai pada tanggal 1 Maret 2016 hingga 6 Maret 2016, dengan mengumpulkan sampel pra uji sebanyak 30 responden.

Hasil yang peneliti dapat berdasarkan data pra uji adalah terdapat total lima butir pernyataan yang tidak valid dan harus dihilangkan dari kuesioner, sedangkan untuk ketiga variabel dinyatakan reliabel. Pernyataan pada kuesioner mencakup kedua variabel yang digunakan dalam penelitian dan memiliki total 18 pertanyaan, yaitu terdiri dari tujuh pernyataan tentang kekuatan informasi pada film NGENEST dan sebelas pernyataan tentang penilaian masyarakat

Setelah melakukan uji validitas dan reliabilitas, peneliti menunggu selang waktu selama 15 hari untuk dapat kembali turun ke lapangan dan menyebarkan kuesioner, hal ini dilakukan karena sampel yang digunakan untuk pra uji dan survei merupakan orang yang sama. Terdapat beberapa kendala yang dihadapi oleh peneliti selama proses mengumpulkan data dari responden. Pertama, adanya masalah jarak dan waktu yang menghambat peneliti untuk mendatangi satu per satu kegiatan open mic setiap komunitas, sehingga peneliti masih tetap mengandalkan adanya alternatif dengan menggunakan kuesioner online. Kedua, peneliti sedikit mengalami kendala untuk dapat menemui anggota-anggota dalam satu komunitas, karena tidak semua anggota datang secara rutin pada kegiatan open mic. Ketiga, peneliti harus menghubungi satu per satu responden untuk menyebarkan kuesioner online, tetapi ada beberapa responden yang tidak merespon pesan yang peneliti kirim melalui media sosial dan beberapa responden yang tidak bisa dihubungi dalam kurun waktu yang cukup lama.

\section{Hasil Penelitian dan Pembahasan}

Terdapat hubungan yang positif antara variabel X1 (kekuatan informasi pada film NGENEST) terhadap variabel Y (penilaian masyarakat), yaitu sebesar 0,423.

Arti positif dalam hubungan antara variabel X1 dan variabel Y adalah searah, yaitu semakin tinggi kekuatan informasi pada film NGENEST, maka akan semakin tinggi pula penilaian masyarakat. Begitu pula sebaliknya, jika semakin rendah kekuatan informasi pada film NGENEST, maka akan semakin rendah pula penilaian masyarakat. Merujuk pada skala Guilford, angka 0,423 menunjukkan tingkat hubungan yang cukup berarti. Sehingga, apabila kekuatan informasi pada film NGENEST mengalami perubahan, penilaian masyarakat juga mengalami perubahan.

Nilai sig. (2-tailed) antara variabel X1 dengan variabel $\mathrm{Y}$ adalah sebesar 0,000. Nilai $\alpha$ dalam penelitian ini adalah 0,05 . Jika nilai sig $<0,05$, maka terdapat hubungan yang signifikan antara variabel X1 dengan variabel Y. Nilai sig $0,000<0,05$, maka terdapat hubungan yang signifikan antara kekuatan informasi pada film NGENEST dengan penilaian masyarakat. 
Tabel 4. Coefficients ${ }^{\mathrm{a}}$

\begin{tabular}{|c|c|c|c|c|c|c|}
\hline \multicolumn{2}{|c|}{ Model } & \multicolumn{2}{|c|}{ Unstandardized Coefficients } & \multirow{2}{*}{$\begin{array}{c}\text { Standardized } \\
\text { Coefficients }\end{array}$} & \multirow[t]{2}{*}{$\mathrm{t}$} & \multirow[t]{2}{*}{ Sig. } \\
\hline & & $\mathrm{B}$ & Std. Error & & & \\
\hline \multirow{2}{*}{1} & (Constant) & 3.037 & .345 & & 8.810 & .000 \\
\hline & $\mathrm{X} 1$ & .365 & .083 & .423 & 4.399 & .000 \\
\hline
\end{tabular}

Sumber: Hasil Pengolahan Data SPSS

Tabel 5. Model Summary ${ }^{\mathrm{b}}$

\begin{tabular}{cccccccc}
\hline Model & $\mathrm{R}$ & $\mathrm{R}$ Square & $\begin{array}{c}\text { Adjusted R } \\
\text { Square }\end{array}$ & $\begin{array}{c}\text { Std. Error of the } \\
\text { Estimate }\end{array}$ & \multicolumn{3}{c}{ Change Statistics } \\
\cline { 6 - 9 } & & & & $\begin{array}{c}\text { R Square } \\
\text { Change }\end{array}$ & F Change & df1 \\
\hline 1 & $.423^{\mathrm{a}}$ & .179 & .169 & .38949 & .179 & 19.354 & 1 \\
\hline
\end{tabular}

Sumber: Hasil Pengolahan Data SPSS

Berdasarkan Tabel 5, maka hasil uji regresi menunjukkan persamaan $\mathrm{Y}=3,037$ $+0,365 \mathrm{X} 1$. Jika variabel independen (kekuatan informasi pada film NGENEST) dianggap tidak ada $(\mathrm{X} 1=0)$, maka nilai variabel Y atau penilaian masyarakat adalah sebesar 3,037 satuan. Jika nilai kekuatan informasi pada film NGENEST meningkat satu poin, maka penilaian masyarakat akan meningkat sebesar 0,365 satuan. Tanda koefisien dari regresi masing-masing variabel menunjukkan arah hubungan dari variabel yang bersangkutan. Tanda positif menyatakan hubungan yang searah, yaitu semakin tinggi kekuatan informasi pada film NGENEST (X1), maka semakin tinggi pula penilaian masyarakat (Y).

Pengujian koefisien determinasi pada tabel R Square menunjukkan bahwa kekuatan informasi pada film NGENEST (X1) terhadap penilaian masyarakat (Y) adalah sebesar $0,179 \times 100 \%=17,9 \%$.
Sementara itu, sisanya sebesar $82,1 \%$ dipengaruhi oleh faktor lain yang tidak peneliti masukkan ke dalam penelitian ini. Hasil presentase di atas sebesar 17,9\% berarti kekuatan informasi pada film NGENEST berpengaruh kecil terhadap penilaian masyarakat. Hal ini dapat terjadi karena anggota-anggota komunitas Stand Up Indonesia menganggap film ini sebenarnya memang menarik, namun pesan-pesan yang tersampaikan pada film NGENEST hanya sebatas hiburan semata. Analisis berikutnya menggunaakan uji $\mathrm{t}$ untuk mengetahui pengaruh variabelvariabel independen secara parsial terhadap variabel terikat. Hipotesis untuk uji t adalah sebagai berikut: (Ho) Kekuatan informasi pada film NGENEST tidak memiliki pengaruh yang signifikan terhadap penilaian masyarakat; (Ha) Kekuatan informasi pada film NGENEST memiliki pengaruh yang signifikan terhadap penilaian masyarakat.

Tabel 6. Coefficients ${ }^{\mathrm{a}}$

\begin{tabular}{|c|c|c|c|c|c|c|}
\hline \multirow{2}{*}{\multicolumn{2}{|c|}{ Model }} & \multicolumn{2}{|c|}{ Unstandardized Coefficients } & \multirow{2}{*}{$\begin{array}{c}\text { Standardized } \\
\text { Coefficients }\end{array}$} & \multirow[t]{2}{*}{$\mathrm{t}$} & \multirow[t]{2}{*}{ Sig. } \\
\hline & & $\mathrm{B}$ & Std. Error & & & \\
\hline \multirow{2}{*}{1} & (Constant) & 3.037 & .345 & & 8.810 & .000 \\
\hline & $\mathrm{X} 1$ & .365 & .083 & .423 & 4.399 & .000 \\
\hline
\end{tabular}

Sumber: Hasil Pengolahan Data SPSS 
Jika t hitung $\geq \mathrm{t}$ tabel, maka Ho ditolak dan Ha diterima, sedangkan jika t hitung $\leq$ t tabel, maka Ho diterima dan Ha ditolak. Jika sig $>0,05$, maka Ho diterima dan Ha ditolak, sedangkan jika sig $<0,05$, maka Ho ditolak dan Ha diterima.

Pada Tabel 5 menunjukkan hasil $\mathrm{t}$ hitung untuk variabel $\mathrm{X}$ adalah sebesar 4.399 dengan nilai signifikansi sebesar 0,000 . Nilai t tabel pada signifikansi 0,05 uji dua pihak dengan $\mathrm{dk}=91-2=89$ adalah 1,986. Jadi t hitung 4,399 $>\mathrm{t}$ tabel 1,986. Nilai sig $0,000<\operatorname{sig} 0,05$, maka Ha diterima dan hal ini menunjukkan bahwa kekuatan informasi pada film NGENEST memiliki pengaruh secara signifikan terhadap penilaian masyarakat.

Penelitian ini merupakan penelitian kuantitatif eksplanatif yang bertujuan untuk menjelaskan masalah yang hasilnya dapat digeneralisasi dan tidak mementingkan adanya kedalaman data atau analisis dan bermaksud untuk meneliti keterkaitan hubungan atau pengaruh antara dua atau lebih variabel independen dengan variabel dependen. Pada penelitian ini yang menjadi variabel independen adalah kekuatan informasi pada film NGENEST (X). Sedangkan variabel dependen adalah penilaian masyarakat (Y). Hasil data-data yang peneliti dapat melalui penyebaran kuesioner terhadap ke-91 responden kemudian diolah menggunakan uji data secara holistik untuk mengetahui seberapa besar pengaruh yang diberikan oleh variabel independen terhadap variabel dependen. Analisis terhadap hasil data-data tersebut selanjutnya akan dihubungkan dengan teori-teori yang peneliti gunakan dalam penelitian ini, karena sifat dari penelitian kuantitatif juga bertujuan untuk menguji teori, agar teori yang digunakan dapat menjelaskan fenomena yang ditelaah.

Hasil uji korelasi parsial yang dilakukan pada variabel $\mathrm{X}$ terhadap $\mathrm{Y}$ menunjukkan bahwa kekuatan informasi pada film NGENEST memiliki hubungan yang cukup berarti terhadap penilaian masyarakat dan memiliki pengaruh yang signifikan terhadap penilaian masyarakat karena hasil uji t hipotesis menyatakan bahwa Ha diterima dan Ho ditolak. Besarnya koefisien determinasi untuk mengetahui pengaruh variabel kekuatan informasi terhadap penilaian masyarakat adalah sebesar $17,9 \%$. Sehubungan dengan teori penggabungan informasi yang digunakan untuk menerangkan variabel $\mathrm{X}$, maka dapat dijelaskan bahwa informasi yang terdapat dalam film NGENEST cukup memiliki kekuatan yang dapat mempengaruhi sistem kepercayaan individu. Informasi yang terdapat dalam film NGENEST dapat dikatakan memiliki valensi atau arahan informasi yang positif dan mendukung kepercayaan yang ada dalam diri seseorang karena mayoritas responden cenderung menjawab setuju terhadap informasiinformasi yang ada dalam film NGENEST. Seperti yang dikatakan dalam teori penggabungan informasi, sebuah arah dan tujuan memengaruhi bagaimana informasi dapat merubah keyakinan seseorang dan bobot memengaruhi seberapa banyak pengaruh itu bekerja. Jika dihubungkan dengan hasil pada pengolahan data 
kuesioner, yakni pengaruh variabel $\mathrm{X} 1$ terhadap Y adalah sebesar 17,9\%, hal ini mengindikasikan bahwa informasi dalam film NGENEST cukup memiliki bobot, namun hanya sedikit pengaruhnya terhadap sistem kepercayaan individu dan berpotensi untuk merubah perilaku atau sikap seseorang terhadap adanya isu-isu berkaitan dengan diskriminasi terhadap keragaman budaya di Indonesia.

\section{Simpulan}

Variabel kekuatan informasi pada film NGENEST memiliki pengaruh yang signifikan terhadap variabel penilaian masyarakat. Hasil analisis data menunjukkan pengaruh sebesar $17,9 \%$ yang kemudian dapat disimpulkan bahwa menurut teori penggabungan informasi, konten yang terdapat dalam film NGENEST cukup memiliki arahan dan bobot yang kuat, sehingga dapat memberikan kontribusi atau pengaruh yang signifikan terhadap penilaian masyarakat. Adapun rekomendasi hasil penelitian ini ditujukan bagi peneliti berikutnya agar dapat lebih mendalami lagi mengenai adanya pengaruh film terhadap sistem kognitif penonton dan faktor-faktor lain yang memungkinkan adanya pengaruh yang lebih besar terhadap penilaian masyarakat khususnya mengenai permasalahan diskriminasi etnis. Di sisi lain bagi Ernest Prakasa selaku komika yang menulis, menyutradarai sekaligus pemain film dianggap perlu lebih memperdalam materi dan mengemasnya dalam bentuk film dengan memperjelas pesan apa yang ingin disampaikan kepada penonton. Selain itu, kerja dunia perfilman diharapkan dapat melakukan pengemasan film dengan lebih baik lagi dan lebih menekankan pesanpesan yang ingin disampaikan, tidak hanya sampai pada tataran hiburan semata. Semoga masyarakat luas lebih memahami pesan-pesan yang tersirat dalam film, tidak hanya sebagai sarana hiburan saja, tetapi apa yang sebenarnya mau dipelajari dari pesan-pesan tersebut, mencoba untuk lebih awas dengan adanya perlakuan dan tindak diskriminasi yang masih marak terjadi di Indonesia, serta menjunjung tinggi asas Bhinneka Tunggal Ika dengan tindakan nyata.

\section{Daftar Pustaka}

Film Indonesia.or.id. (2015). "Daftar 10 Film Indonesia Peringkat Teratas 2015". Tersedia dari: http://www.jadwal21. com/p/2015.html.

Griffin, Em. (2012). A First Look at Communication Theory. New York: McGraw-Hill.

Kriyantono, Rachmat. (2012). Teknik Praktis: Riset Komunikasi. Jakarta: Kencana Prenada Media Group.

Littlejohn, Stephen W. and KarenA. Foss. (2008). Theories of Human Communication $9^{\text {th }} e d$. USA: Wadsworth Cengage Learning. (2011). Teori Komunikasi edisi 9. Jakarta: Salemba Humanika.

Powers, P. (2007). Persuasion and Coercion: A Critical Review of Philosophical and Empirical Approaches. HEC Forum, 19(2).

Soemirat, Soleh dan Asep Suryana. (2014). Komunikasi Persuasif. Jakarta: Universitas Terbuka. 
Sugiyono. (2011). Statistika untuk Penelitian catatan ke-18. Bandung: Alfabeta.

Suryadinata, Leo. (2010). Etnis Tionghoa dan Nasionalisme Indonesia. Jakarta: Kompas.

Undang-Undang No. 33 Tahun 2009 tentang Perfilman.
Wijono, Sutarto. (2010). "Penghayatan Subyektif Terhadap Stress Berdasarkan Teori Lazarus". ENQUIRY: Jurnal Ilmiah untuk Peningkatan Profesional, Universitas Kristen Satya Wacana, 3(1). 